\title{
Anti-Vibrio Activity of Parkia javanica: Studies on MIC, MBC, Growth Curve Analysis and ROS Generation on Four Vibrio cholarae Strains
}

\section{Susmita Saha ${ }^{1}$, Jhinuk Basu Mullick ${ }^{1}$, Parichita Ray Choudhury ${ }^{1}$, Partha Saha ${ }^{1}$, Debaprasad Chakraborty ${ }^{2}$ and Samir Kumar Sil ${ }^{1}$ *}

\author{
${ }^{1}$ Molecular Genetics and Cell Physiology Lab., Department of Human Physiology, Tripura \\ University, Suryamaninagar, West Tripura-799022, India \\ ${ }^{2}$ Department of Pathology, Tripura Medical College, Hapania, West Tripura-799014, India
}

*Corresponding author

\section{A B S T R A C T}

Keywords

Parkia javanica, Vibrio cholerae, growth curve, ROS.

\section{Article Info}

Accepted:

23 July 2016

Available Online:

10 August 2016
Parkia javanica, a medicinal plant, of North-East India, was screened for anti cholera activity against 4 Vibrio cholarae strains. Fresh stem barks of Parkia javanica was collected and crude methanol extract of Parkia javanica (MEPJ) was prepared by Hahnshin rotary evaporator. The minimum inhibitory concentration of MEPJ was evaluated on Vibrio cholarae strains by serial dilution technique. $10 \mathrm{mg} / \mathrm{ml}$ of MEPJ is the $\mathrm{IC}_{100}$ dose for Vibrio cholarae strains. MEPJ also showed bactericidal activity against all four Vibrio cholarae at the same concentration. The lag phase become extended after treatment with $\mathrm{IC}_{50}$ dose of MEPJ. Intracellular reactive oxygen species (ROS) was increased $(40 \%-60 \%)$ in presence of MEPJ indicating ROS mediated mechanism of growth inhibition.

\section{Introduction}

Vibrio cholerae, a Gram-negative, facultative anaerobic, comma shaped bacterium, is the causative agent of life threatening diarrheal disease called cholera (Pacini, 1854). In developing countries, infectious diseases are the important factors for morbidity and mortality in common people (Mattana et al., 2012). Parkia javanica is a very large tree and has found traditional use as food and ethnomedicine in North- East India (Maiti, 2004). It is generally used by tribal population of NorthEast India to cure stomach ache, dysentery, food poisoning (Majumder et al., 2009).
Saha et al., 2007, reported that, Parkia javanica has antibacterial activities against both standard Gram positive and Gram negative bacterial strains. But there is no report, on anti-vibrio activity of Parkia javanica against Vibrio cholerae strains. Therefore, this work has been undertaken to explore the anti-vibrio activities of $P$. javanica using crude methanol extract.

\section{Materials and Methods}

\section{Preparation Plant Extract}

Fresh stem barks of Parkia javanica was collected from Suryamaninagar, Tripura, 
India. After washing with water these barks were allowed to dry in shade. Then barks were cut into small pieces. Then $500 \mathrm{gm}$ of powdered bark was soaked in $2000 \mathrm{ml}$ of methanol to prepare the crude extract and kept in a shaker for 48 hours. After that the solutions were filtered through Whatman filter paper no. 1 for 3 times. Then these solutions were dried in rotary evaporator at $70^{\circ} \mathrm{C}$. Finally these solutions were freezedried and stored at $-20^{\circ} \mathrm{C}$ (Nikolic et al., 2014).

$100 \mathrm{mg}$ of dried extract was dissolved in $1 \mathrm{ml}$ of $25 \%$ DMSO-water mixture and filtered by a $0.22 \mu \mathrm{m}$ syringe filter and stored at $-20^{\circ} \mathrm{C}$.

\section{Bacterial Strains and Growth Conditions}

Vibrio cholarae 097 VTE 2357, Vibrio cholarae 06 VTE 2523, Vibrio cholarae classical Y 1254, Vibrio cholarae 01 hybrid 02459 strains were grown, cultured and maintained in Muller Hinton Broth and Muller Hinton agar. For long time storage $15 \%$ glycerol solution was used and vial was stored at $-80^{\circ} \mathrm{C}$ (Bhattacharya et al., 2012).

\section{Determination of Minimum Inhibitory Concentration (MIC)}

MIC was determined by serial dilution technique, with an inoculums of $10^{6} \mathrm{CFU} / \mathrm{ml}$ of both Gram positive and Gram negative bacteria in separate 96 well plates, in presence of increasing concentrations of MEPJ. The bacterial cultures were incubated at $37^{\circ} \mathrm{C}$ and shaken at $200 \mathrm{rpm}$ for 24 hours. Then the bacterial cell viability was determined by measuring the OD value at $600 \mathrm{~nm}$. Here, MEPJ with media, used as blank; media, MEPJ and bacterial culture, used as experiment; media with bacterial culture and 25\% DMSO, used as positive control; and media with only $25 \%$ DMSO, used as negative control (Demetrio et al.,
2015). Then, \% of Inhibition was calculated by following formula,

$\%$ of Inhibition $=$

[1- \{(Exp. - Blank) / (Positive Control Negative Control) $\}^{*}$ 100]

\section{Determination of Minimum Inhibitory Concentration (MBC)}

After determining the MIC values, MBCs for each bacterial species were examined by treating the each bacterial species with 3 different doses, $\mathrm{IC}_{50}, \mathrm{IC}_{100}$ and $>\mathrm{IC}_{100}$ dose. After incubation with these 3 doses, one loop full bacterial culture from each tube was streaked on Muller Hinton agar plate in absence of extract and again these plates were incubated at $37^{\circ} \mathrm{C}$ for overnight. $\mathrm{IC}_{100}$ value indicates the concentration which inhibits $100 \%$ of bacterial growth, whereas, MBC value indicates the concentration at which a drug can kill the bacterial species (Demetrio et al., 2015).

\section{Measurement of Bacterial growth Kinetics}

To determine the bacterial growth kinetics, in presence of MEPJ, each bacterial species were grown in Muller Hinton Broth in presence and absence of MEPJ separately, at $37 \mathrm{C}$ at $200 \mathrm{rpm}$ for 12 hours. Here, bacterial cells were treated with respective $\mathrm{IC}_{50}$ dose. Then, the bacterial concentration in presence and absence of MEPJ were determined by measuring the OD at $600 \mathrm{~nm}$ in every 1 hour interval. Bacterial growth kinetics was plotted graphically with time versus $\mathrm{OD}_{600}$ (Bhattacharya et al., 2012).

\section{Estimation of Reactive Oxygen Species (ROS)}

The bacterial suspension $(0.1 \mathrm{ml})$ (where $\left.\mathrm{OD}_{600}=1.0\right)$ in Hank's balanced salt 
solution (HBSS) was incubated with respective $\mathrm{IC}_{50}$ dose of MEPJ for 3 hours with $15 \mathrm{~min}$ interval at $37^{\circ} \mathrm{C}$. Then $500 \mu \mathrm{l}$ of $1 \mathrm{mg} / \mathrm{ml}$ NBT was added and again incubated for $30 \mathrm{~min}$ at $37^{\circ} \mathrm{C}$. After incubation, 0.1 (M) $\mathrm{HCl}$ was added and tubes were centrifuged at $3000 \mathrm{rpm}$ for 10 min. The pellets were treated with $0.6 \mu \mathrm{l}$ of DMSO to extract the reduced NBT. Then, $0.5 \mu \mathrm{l}$ of HBSS was added and OD was measured at $575 \mathrm{~nm}$ (intracellular ROS) (Pramanik et al., 2012).

\section{Statistical Analysis}

We repeated these experiments for 3 times and data were expressed by calculating the standard deviation of all 3 experiments. ANOVA single factor (using Microsoft Office Excel) was used to determine statistical significance for multiple comparisons. $P<0.05$ was accepted as statistically significant.

\section{Results and Discussion}

\section{Minimum Inhibitory Concentration}

Antibacterial activity of MEPJ on Vibrio cholerae strains were obtained by determining the minimum inhibitory concentrations. The growth of Vibrio cholerae strains were inhibited completely at concentrations of $10 \mathrm{mg} / \mathrm{ml}$ of MEPJ, but the order of observed $\mathrm{IC}_{50}$ dose on 4 bacterial strains were, VC 097 VTE $2357>$ VC 06 VTE $2523>$ VC classical Y $1254>$ VC 01 hybrid 02459 [Table 1].

\section{Minimum Bactericidal Concentration}

Minimum bactericidal concentration of MEPJ on each bacterial strain was also determined as shown in Fig. 1. The ratio between MBC and MIC for each bacterium is same $(\sim 1$, for all bacteria) [Table 2]. This result indicated that, MEPJ is a bactericidal agent rather than bacteriostatic agent.

\section{Bacterial Growth Kinetics Studies}

We next measured the growth curve of all these bacterial strains to examine whether MEPJ kill or inhibit the growth of these bacteria. Both the bacterial strains were exposed to MEPJ separately, at a concentration of $\mathrm{IC}_{50}$ dose for each bacterium. As shown in Fig 2, the lag phase of all MEPJ treated bacteria were extended compared to control.

Table.1 MIC values for Vibrio cholarae Strains. (This data is significant at a level of $p<0.05$ )

\begin{tabular}{|l|c|c|}
\hline & $\begin{array}{c}\mathbf{I C}_{\mathbf{5 0}} \\
(\mathbf{m g} / \mathbf{m l})\end{array}$ & $\begin{array}{c}\mathbf{I C}_{\mathbf{1 0 0}} \\
(\mathbf{m g} / \mathbf{m l})\end{array}$ \\
\hline Vibrio cholerae classical Y 1254 & $5.5 \pm 0.43$ & $10 \pm 0.22$ \\
\hline Vibrio cholerae 06 VTE 2523 & $5 \pm 0.18$ & $10 \pm 0.24$ \\
\hline Vibrio cholerae 097 VTE 2357 & $4.5 \pm 0.34$ & $10 \pm 0.27$ \\
\hline Vibrio cholera 01 hybrid 02459 & $6 \pm 0.41$ & $10 \pm 0.49$ \\
\hline
\end{tabular}


Table. $2 \mathrm{MBC}$ values for Vibrio cholerae Strains. (This data is significant at a level of $\mathrm{p}<0.05$ )

\begin{tabular}{|l|c|c|}
\hline & $\begin{array}{c}\text { MBC } \\
(\mathrm{mg} / \mathrm{ml})\end{array}$ & MBC/MIC \\
\hline Vibrio cholerae classical Y 1254 & $10 \pm 0$ & 1 \\
\hline Vibrio cholerae 06 VTE 2523 & $10 \pm 0$ & 1 \\
\hline Vibrio cholerae 097 VTE 2357 & $10 \pm 0$ & 1 \\
\hline Vibrio cholera 01 hybrid 02459 & $5 \pm 0$ & 1 \\
\hline
\end{tabular}

Fig.1 Muller Hinton Agar Plate showing MBC of Vibrio cholerae strains. A- Vibrio cholerae classical Y 1254, B- Vibrio cholerae 06 VTE 2523, Vibrio cholerae 097 VTE 2357, Vibrio cholerae 01 hybrid 02459.
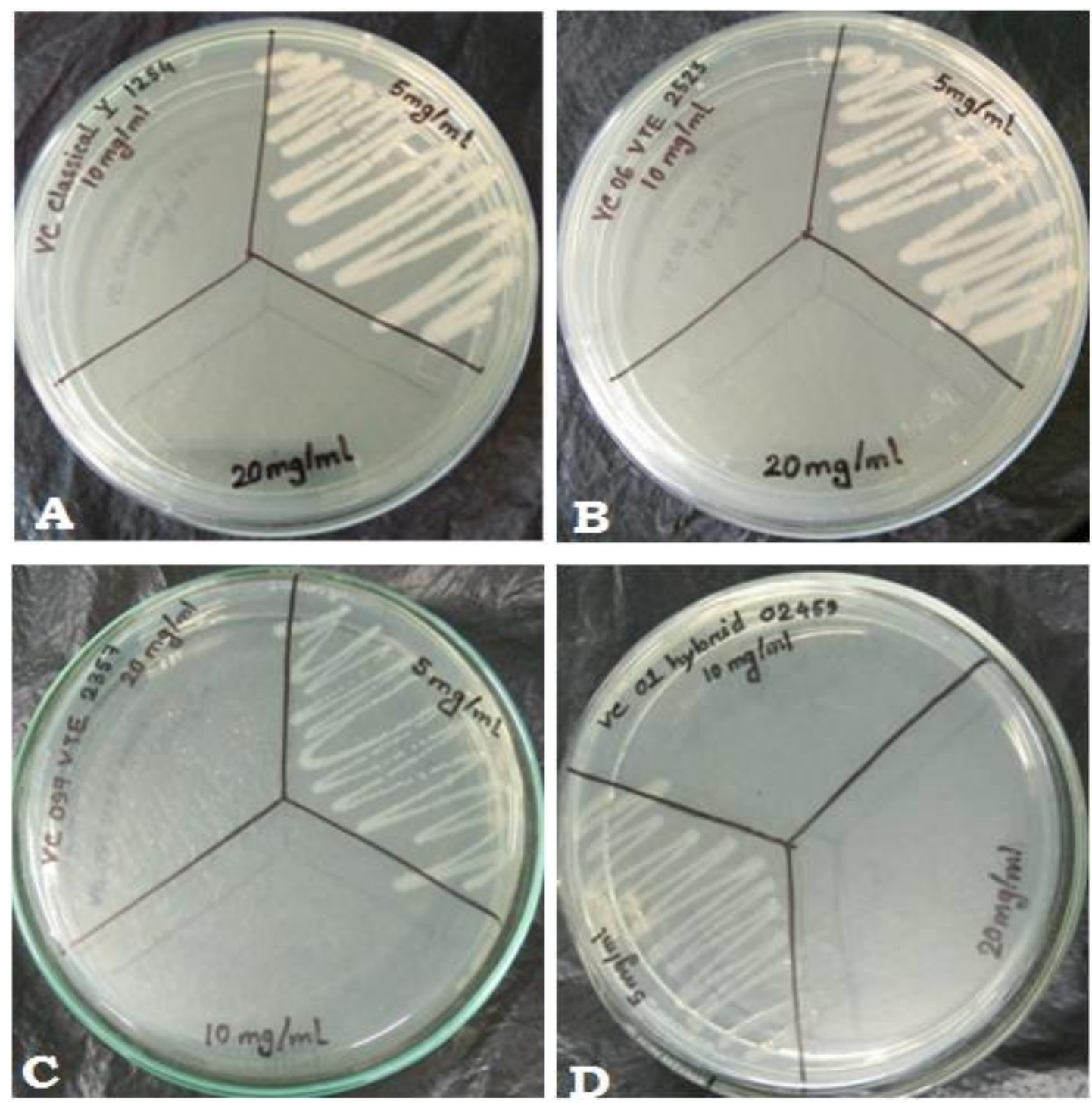
Fig.2 Growth curve of Vibrio cholerae strains in presence and absence of MEPJ.

This data is significant at a level of $\mathrm{p}<0.05$

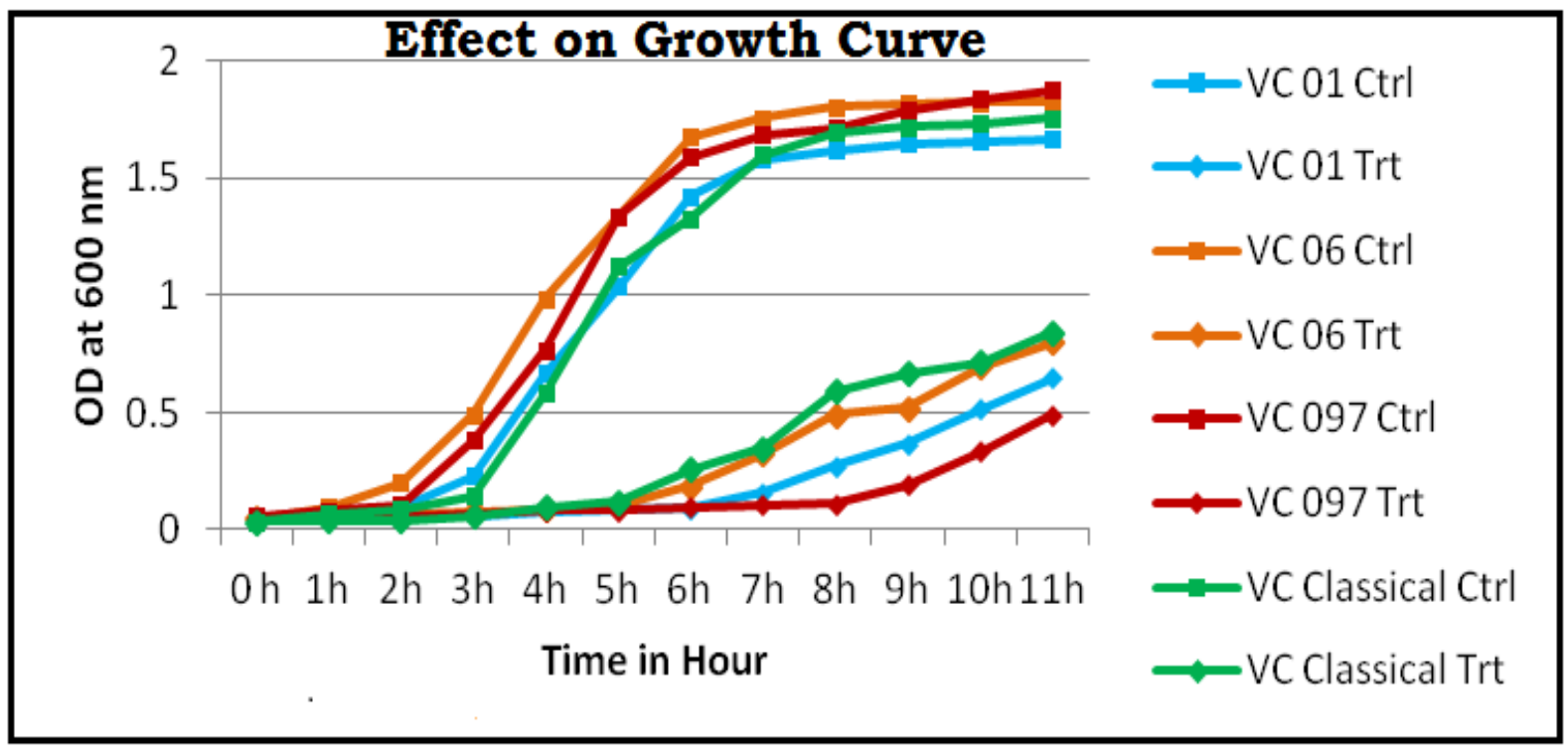

Fig.3 Normalized \% of ROS produced by Vibrio cholerae strains in presence of MEPJ. This data is significant at a level of $\mathrm{p}<0.05$.

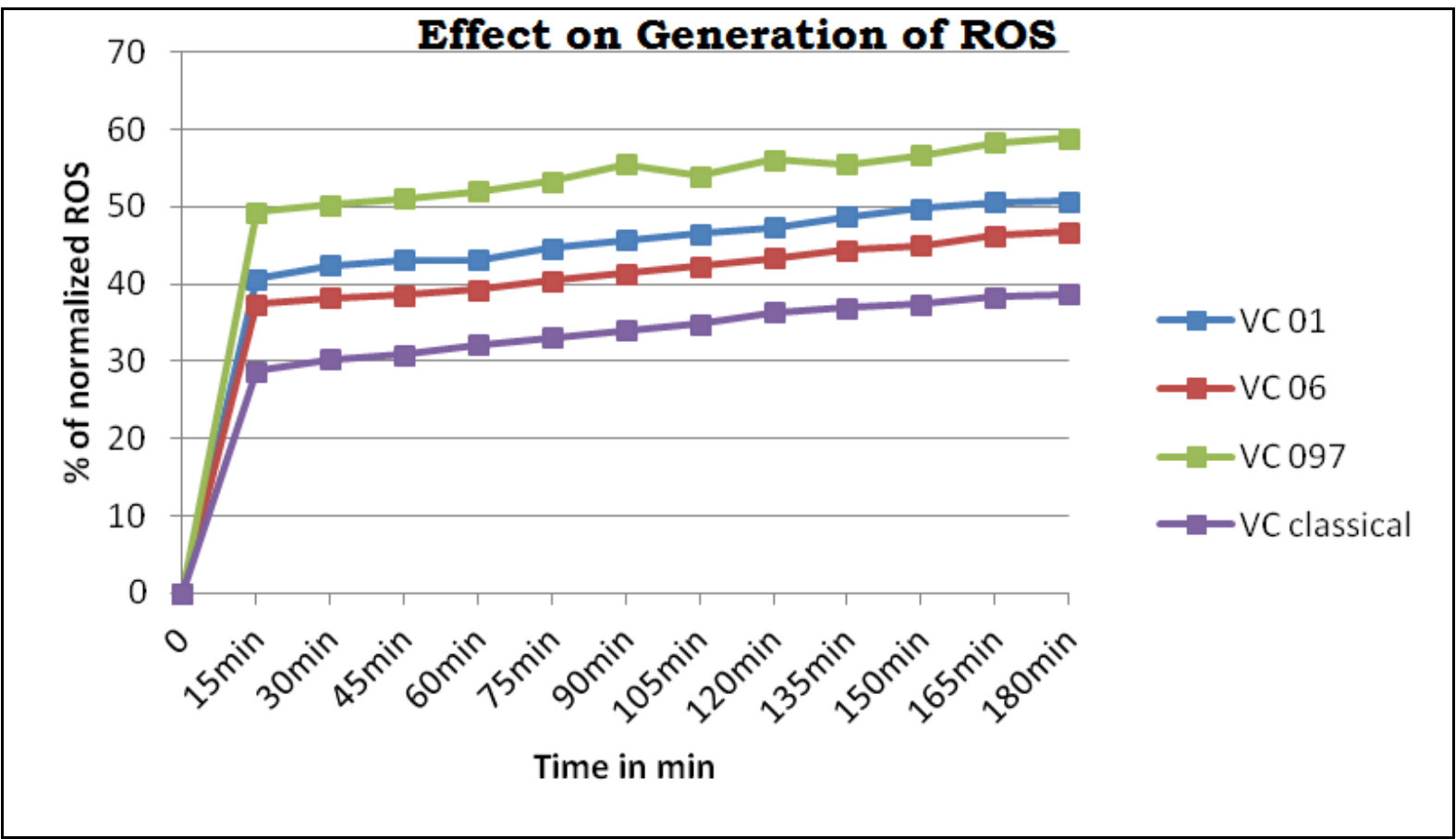

\section{Generation of Reactive Oxygen Species} (ROS)

Finally, to understand the mechanism of antibacterial activity of MEPJ, intracellular reactive oxygen species (ROS) was estimated after treatment with MEPJ at $\mathrm{IC}_{50}$ dose. As shown in Fig 3, after treatment of MEPJ, the production of ROS was increased drastically with time. It was highest in $V C$ 
097 VTE 2357, in which ROS production increased about $60 \%$ in 3 hours compared to control, whereas in VC classical Y 1254, ROS production increased about $35 \%$. The order of observed ROS production on 4 Vibrio cholerae bacterial strains were, $V C$ 097 VTE $2357>V C 01$ hybrid $02459>V C$ O6 VTE 2357 > VC classical Y 1254.

Several studies reported that, different edible and medicinal plants had anti-vibrio and vibriocidal activities (Sanchez et al., 2010; Fakruddin et al., 2011). In this study we have reported the anti-vibrio activity of crude methanol extract of $P$. javanica against 4 Vibrio cholerae strains namely Vibrio cholarae 097 VTE 2357, Vibrio cholarae 06 VTE 2523, Vibrio cholarae classical Y 1254, Vibrio cholarae 01 hybrid 02459. From this study it was observed that, the extract possessed both bacteriostatic and bactericidal activity. At $10 \mathrm{mg} / \mathrm{ml}$ dose, all the strains were got killed. From growth kinetics study, we found that, the lag phase of all extract treated bacteria is extended compared to untreated cells. The normalized $\%$ of ROS was also increased in almost every strain after extract treatment. Therefore, it could be conclude that, the crude methanol extract of Parkia javanica possesses anti-vibrio activity and ROS induced bacterial cell damage is the possible mechanism of this anti-vibrio activity.

\section{Acknowledgements}

We acknowledge Dr. Amit Pal, Scientist, NICED, Beleghata, Kolkata, West Bengal for giving us 4 Vibrio cholarae strains.

\section{References}

Bhattacharya, D., Samanta, S., Mukherjee, A., Santra, C.R., Ghosh, A.N., Niyogi, S. K. and Karmakar, P. 2012. Antibacterial Activities of Polyethylene Glycol, Tween 80 and
Sodium Dodecyl Sulphate Coated Silver Nanoparticles in Normal and Multi-Drug Resistant Bacteria. J. Nanosci. Nanotechnol., 12: 1-9.

Demetrio, L.V.J., Jeannie, I.A., Juliana, J.M.P., Esperanza, C.C., Windell, L.R. 2015. Antibacterial activities of ethanol extracts of Philippine medicinal plants against multidrugresistant bacteria. Asian Pac. J. Trop. Biomed., 5(7): 532-540.

Fakruddin, M., Alam, K.M.A., Mazumdar, R.M., Islam, S., Nipa1, M.N., Iqbal, A. and Bhuiyan, H.R. 2011. Antibacterial Activity of the Extract of Terminalia arjuna Against Multi Antibiotic Resistant Vibrio cholerae. J. Sci. Res., 3(1): 129-137.

Pacini, F. 1854. Osservazioni microscopiche e deduzioni patologiche sul cholera asiatico" (Microscopic observations and pathological deductions on Asiatic cholera). Gazzetta Medica Italiana: Toscana, 2nd series, $4(50): 397-$ 40; 4 (51): 405-412.

Mabeku, L.B.K., Emmanuel, T., Kouam, J., Zra, T. and Louis, O.E.J. 2013. Synergetic effects of plant extracts and antibiotics on Vibrio cholerae $\mathrm{O} 1$ strains isolated from clinical specimens. Int. J. Biol., 5(3): 64-72.

Majumder, K., Dutta, B.K. and Roy, D. 2009. Inventory and status of medicinal trees of Tripura. Indian Medicinal Plants editor P. C. Trivedi. Avishkar publishers, Distributors. Jaipur. pp 93- 123.

Maiti, G.G. 2004. Plant diversity of India and its conservation, utilization with special reference to N. E. region. In: Proc. Sem. Biodiversity, Tripura University. India pp. 6.

Mattana, C.M., Satorres, S.E., Escobar, F., Sabini, C., Sabini, L., Fusco, M. and Alcaraz, L.E. 2012. Antibacterial and cytotoxic activities of Acacia aroma 
extracts. Emir. J. Food Agric., 24(4): 308-313.

Nikolic, M., Vasic, S., Durđevic, J., Stefanovic, O. and Comic, L. 2014. Antibacterial and anti-biofilm activity of ginger (Zingiber officinale (roscoe)) ethanolic extract. Kragujevac J. Sci., 36: 129-136.

Pramanik, A., Laha, D., Bhattacharya, D., Pramanik, P., Karmakar, P. 2012. A novel study of antibacterial activity of copper iodide nanoparticle mediated by DNA and membrane damage.
Colloids and Surfaces B: Biointerfaces, 96: 50- 55.

Saha, R., Sil, S.K., Mohanta, B. and Dinda, B. 2007. Antibacterial activity of Parkia javanica -an indigenous medicinal plant of Tripura. $J$. Ecotoxicol. Environ. Monit., 17(1): 15-19.

Sanchez, E., García, S. and Heredia, N. 2010. Extracts of edible and medicinal plants damage membranes of Vibrio cholerae. Appl. Environ. Microbiol., 76(20): 6888-6894.

\section{How to cite this article:}

Susmita Saha, Jhinuk Basu Mullick, Parichita Ray Choudhury, Partha Saha, Debaprasad Chakraborty and Samir Kumar Sil. 2016. Anti-Vibrio Activity of Parkia javanica: Studies on MIC, MBC, Growth Curve Analysis and ROS Generation on Four Vibrio cholarae Strains. Int.J.Curr.Microbiol.App.Sci. 5(8): 538-544. doi: http://dx.doi.org/10.20546/ijcmas.2016.508.058 